\title{
Slutningen af
}

\section{„,Lidet om Jesu Kristi Aabenbaring ...“}

\author{
(Grundtvig-Studier 1956, s. 64-74).
}

\section{Ved Steen Johansen.}

I Grundtvig-Studier 1956 offentliggjorde dr. phil. William Michelsen en tekst af Grundtvig fra efteraaret 1810, hvis fulde titel var »Lidet om Jesu Kristi Aabenbaring ved Apostelen Johannes«. Manuskriptet dertil henlaa i Grundtvig-arkivet $\mathrm{i}$ meget splittet form, saaledes at begyndelsen fandtes $\mathrm{i}$ fascikel I48 (nr. 21), fortsættelsen i fasc. 502, fortsættelsen deraf igen i fasc. I50 (nr. 4). Hvor slutningen var, vidste man ikke. Af disse stykker var nr. I48.2 I blevet fundet af Steen Johansen og ikke tidligere trykt, medens nr. 502 for mange aar siden var blevet fremdraget og meddelt af Holger Begtrup i Grundtvigs Udvalgte Skrifter II, s. 29-31. Nr. I50.4 var blevet fundet og offentliggjort af dr. phil. Gustav Albeck i 1955 (jf. dr. Michelsens oplysninger føranførte sted s. 74 f.). - Siden da er den manglende slutning blevet fundet, forøvrigt i samme fascikel (148), hvori ogsaa begyndelsen fandtes. Det viste sig nemlig, at to mindre manuskripter, som i Grundtvig-registranten havde faaet numrene henholdsvis 22 (4 sider) og 19 ( 2 sider), og som dér var blevet opfattet som prædikenbrudstykker, i virkeligheden - og i den her nævnte rækkefølge - udgjorde den savnede slutning. At nr. I9 var en fortsættelse af $\mathrm{nr}$. 22 var allerede erkendt i Gr.-registranten, derimod blev manuskripternes samhørighed med de førnævnte stykker uheldigvis først opdaget efter registreringen af den paagældende fascikel.

Saaledes blev omsider en tekst-helhed genoprettet, og det anførte er et klart eksempel paa, hvorledes det ikke sjældent forholder sig med manuskripter $\mathrm{i}$ Gr.-arkivet. Registreringen har vist sig at være $\mathrm{i}$ høj grad paakrævet, og opklaringen af manuskriptdeles samhørighed er blevet en ikke uvigtig del af registreringsarbejdet. (Men naar en saadan helhed er konstateret, flyttes manuskriptdelene alligevel ikke sammen, idet den orden, hvori de engang er blevet lagt, anses for urorlig. Her træder Gr.-registranten til som hjælpemiddel til manuskripternes sammenhæng og kronologi.)

Den fundne tekst aftrykkes i det følgende uden særlige kommentarer, idet dr. Michelsens efterskrift til de foregaaende dele af teksten, naturligvis ogsaa gælder for den her trykte slutning. 


\section{(fasc. 148.22:)}

men da opkom et Dyr af Afgrunden, de romerske Paver, hvorom tilforn er talet, at de skammelig misbrugte den Myndighed Gregorius i god Mening havde tiltaget sig, forbød Skriften at læses af menig Mand og gav Befalinger som aabenbar strede imod den ${ }^{1}$ ). Det maatte vel kaldes at slaa den ihjel, men der Herrens Time kom, da stode de[n] atter op og fik Livs Aande, det er da kun Luther og gav den i hver Mands Haand, at han selv kunde se og kende sin Guds Villie. Det Øvrige er vel ikke endnu sket.

Mere vil jeg ikke sige Eder, Brødre! thi mere er ei aldeles lyst for mig, og bedrage eder derfor bevare mig den levende Gud; men skulde det hændes i eders Dage, hvad sikkerlig engang vil ske, at Nogen vil befale eder eller lokke eder til at tilbede Paven eller nogen Anden end Gud den treenige, da husker det vel, at ogsaa dette har Guds Aand forudsagt ved Johannes, at det skulde engang ske! Da husker det vel at jeg haver advaret eder i den levende Guds Navn, paa det I maatte bestaa i Fristelsens Stund og frelse eders Sjæle. Agter det vel, jeg siger ikke, at det vil ske, thi det veed jeg ikke, men om det sker, da værer aarvaagne, og agter det ei, om der end ske Tegn og underlige Gerninger for eders Øine! Men opleve I det ikke, da advarer eders Børn!

Og nu mine Kristne! fordyber eder ikke selv i denne hemmelighedsfulde Aabenbaring, thi dertil ere I ikke kaldede, den kan kun begribes stykkevis, alt eftersom det er sket hvad derudi spaaes, og det kun af den, som kender de forbigangne Tiders Hændelser og som Herren da vil give sin Naade. Grubler ikke heller over de Ting som skal ske, men værer faste i Troen og god Gernings Øvelse, som det sømmer sig dem, der have annammet Kristi Evangelium og Tegn paa dets Sandhed! Dersom Nogen siger til Eder, at I ved eders Gerninger kunne fortjene Himmelen, og at I ei behøve at tro paa den Korsfæstede || og tilegne eder hans Fortjeneste, da for Guds og eders udødelige Sjæles Skyld, troer dem ikke, thi det vide vi jo af Skriften at vi retfærdiggøres af Naade, ei efter nogen egen Fortjeneste saa at ingen kan rose sig; naar vi have gjort Alt hvad vi kunne have vi dog ikke gjort Andet end hvad vi ere skyldige at gøre. Men dersom Nogen siger til Eder at det er Nok til Salighed naar I tro at

1) Jvf. Grundtvig-Studier 1956, s. 7I f. 
Kristus er død for vore Synder, og opstanden til vor Retfærdighed, uden at vi behøve at beflitte os paa et gudeligt ærbart og retfærdigt Levnet, o da troer ei heller ham, thi den samme Johannes, hvis Spaadom er givet os til et Tegn, har jo selv sagt, at hvo som siger at han elsker Gud men hader sin Broder, han er en Løgner, og Apostelen Jakob vidner, at ligesom Legemet er dødt uden Aand, saa er og Troen død uden Gerninger, ja Jesus || Kristus vor guddommelige Forløser har jo selv erklæret høitidelig: ikke enhver, som siger til mig Herre, Herre, skal komme ind i Himmeriges Rige, men kun den, som gør min himmelske Faders Villie.

O saa vogter eder da, mine Brødre og Søstre for Vantro og Synd! frygter Gud! ærer Kongen! elsker Fædrenelandet! Ak for det ere Tiderne onde, men det er vore Synders Skyld allene, vende vi alvorlig om til vor Gud, da vil han forlene os Størke til, med Glæde at opofre Gods og Liv og Blod, naar Fædrenelandets, det gamle Dannemarks Vel og Frelse udkræver det. Saaledes gjorde vore gamle Fædre, som troede og haabede paa Gud og Salighed og nu ere hensovne i Herren. Men ak! I have glemt Gud og I have glemt eders Forfædre, derfor have Mange af eder ikke Størke til at staa fast paa

$$
\text { (fasc. 148.19:) }
$$

Stridens Dag, derfor have saamange af eder ikke Villie til at yde eders Skærv til Landets Nødtørft. Mine Brødre! disse Ting bør ikke saaledes at være! vore jordiske Sysler skulle vi ikke forsømme, thi vi skal æde vort Brød i vort Ansigts Sved men vi skulle ikke samle Liggendefæ paa Jorden, vi gøre det i Sandhed ikke heller, dersom vi have fast Tro paa Gud og urokkeligt Saligheds Haab! O, strider at I kan vinde disse Klenodier, da faae I Rolighed i Hjertet, og Mod til at gaa i Døden, naar Herren kalder, hvad enten det saa er paa Krigens Mark eller og paa Sotteseng. Ogsaa jeg vil da arbeide for Eder, Bibelen have I og det maa være eders dyrebareste Skat, men det sømmer sig ogsaa for eder at vide, hvorledes Gud har styret Tingenes Gang i Verden indtil denne Dag, paa det I kan størkes i Troen, og forstaa Spaadommene, naar de opfyldes. Det sømmer sig ogsaa for eder at kende eders || Forfædre, dem som have levet i de[t] samme Land, dyrket den samme Gud, og talet med det samme Tungemaal, paa det I maa glædes i eders Aand, naar I læse om deres Gudsfrygt og mandelige Gerninger og opmuntres desmere til at ligne 
dem. [Efter »dem.« følger overstreget: saa og at I kunne vogte]. Alt dette vil jeg om Gud den almægtige under mig Liv og Størke fremstille for eder, saa at I kunne forstaa det, men er det ikke Guds Villie, at jeg skal fuldkomme det, da opvækker han sikkerlig en Anden efter mig; og tager dem med Tak, saadanne Bøger, elsker dem og holder dem i Ere næst efter Herrens livsalige Ord, da skulle eders Børn opreises i Gudsfrygt og Kundskab, til eders Glæde, Fædrenelandets Størke og Pris og eders Sjæles evige Salighed. Amen.

Barmhjertighed, Naade og Fred af Gud vor Fader og af Herren Jesu Kristo Faderens Søn, være i Sandhed og Kærlighed med eder Alle. 